\begin{tabular}{l} 
Univerzitet u Beogradu \\
Poljoprivredni fakultet \\
Institut za poljoprivrednu tehniku \\
Naučni časopis \\
POLJOPRIVREDNA TEHNIKA \\
Godina XLIV \\
Broj 4, 2019. \\
Strane: $39-49$ \\
\hline $\begin{array}{r}\text { University of Belgrade } \\
\text { Faculty of Agriculture }\end{array}$ \\
Scientific Journal \\
Institute of Agricultural Engineering \\
AGRICULTURAL ENGINEERING \\
Year XLIV \\
No.4, 2019. \\
pp: $39-49$
\end{tabular}

\title{
ASSESSEMENT OF SITTING ANTHROPOMETRY OF MALE AND FEMALE TRACTOR OPERATORS IN ABIA STATE
}

\author{
Goziechukwu Inekwe ${ }^{1}$, Okechukwu Oduma ${ }^{1 *}$, Chukwulebile S. Agu $^{2}$, \\ Clifford E. Igboayaka ${ }^{2}$ and Chineze G. Okeke ${ }^{3}$ \\ ${ }^{I}$ Department of Agricultural \& Bioresources Engineering, \\ Michael Okpara University of Agriculture, Umudike \\ ${ }^{2}$ Department of Mechanical Engineering, \\ College of Engineering and Engineering Technology, \\ Michael Okpara University of Agriculture, Umudike, Abia state, Nigeria. \\ ${ }^{3}$ Department of Agricultural and Bioresources Engineering, \\ Enugu state University of Science and Technology, Enugu
}

\begin{abstract}
The anthropometric body dimensions of the tractor operators in Abia state (Nigeria) where studied to obtain a database for their anthropometric body dimensions to enable the designers of tractors and agricultural equipment operated in sitting positions improve on their design in order to optimize their usage, enhance posture and comfort of the users and maximize output. Result revealed that the male agricultural workers have average hand length, hand breadth, arm reach from wall, elbow height, elbow rest height, grip strength, internal and external grip diameters, hand circumference, forearm length and forward grip reach of male agricultural workers are $161.05 \mathrm{~cm}$, $49.1 \mathrm{~cm}, 143.75 \mathrm{~cm}, 38.25 \mathrm{~cm}, 19.55 \mathrm{~cm}, 8.65 \mathrm{~cm}, 85.75 \mathrm{~cm}, 104.25 \mathrm{~cm}, 24.9 \mathrm{~cm}, 41.6 \mathrm{~kg}$, $4.7 \mathrm{~cm}, 7.35 \mathrm{~cm}, 7.35 \mathrm{~cm}, 49.9 \mathrm{~cm}$ and $75.2 \mathrm{~cm}$ respectively while in that same order the female agricultural workers recorded $150.55 \mathrm{~cm}, 38.9 \mathrm{~cm}, 138.6 \mathrm{~cm}, 36.45 \mathrm{~cm}, 18.15 \mathrm{~cm}$, $7.2 \mathrm{~cm}, 82.35 \mathrm{~cm}, 100.4 \mathrm{~cm}, 22.25 \mathrm{~cm}, 40.25 \mathrm{~kg}, 4.0 \mathrm{~cm}, 6.7 \mathrm{~cm}, 19.55$ and $75.15 \mathrm{~cm}$ respectively. Also result showed that the sitting height, sitting eye height, sitting shoulder height, hip breadth, knee height, buttock knee length, functional leg length, foot length of the male agricultural workers are $80.75 \mathrm{~cm}, 81.8 \mathrm{~cm}, 68.5 \mathrm{~cm}, 54.0 \mathrm{~cm}, 33.0 \mathrm{~cm}$,
\end{abstract}


$55.8 \mathrm{~cm}, 49.7 \mathrm{~cm}, 65.0 \mathrm{~cm}, 57.05 \mathrm{~cm}, 48.65 \mathrm{~cm}, 95.25 \mathrm{~cm}, 32.55 \mathrm{~cm}, 14.35 \mathrm{~cm}$, and $66.05 \mathrm{~cm}$ respectively; and the female in the same arrangement had $85.8 \mathrm{~cm}, 65.59 \mathrm{~cm}, 65.07 \mathrm{~cm}$, $41.38 \mathrm{~cm}, 29.14 \mathrm{~cm}, 49.14 \mathrm{~cm}, 44.97 \mathrm{~cm}, 56.06 \mathrm{~cm}, 47.86 \mathrm{~cm}, 36.58 \mathrm{~cm}, 80.51 \mathrm{~cm}, 27.53 \mathrm{~cm}$, $3.35 \mathrm{~cm}$ and $79.19 \mathrm{~cm}$ respectively.

Key words: Anthropometric, dimensions, operators, tractors, sitting positions.

\section{INTRODUCTION}

Engineering anthropometry deals with the application of scientific physical measurement method to human subjects for the development of engineering design standards. It includes static and functional (dynamic) measurements of dimensions and physical characteristics of the body as they occupy space, move and apply energy to physical objects, as a function of age, sex, occupation, ethnic origin and other demographic variables (Sanders and McCormic 1992).

Agrawal et al., (2010) noted that anthropometric body dimensions play significant roles in human-machine interaction and that the overall working efficiency of humanmachine environment and resultant discomfort has severe impact while using farm tools and machinery. They also noted that anthropometric dimensions vary considerably across gender, race, age, and that within a particular group, the anthropometry differs due to nutritional status and nature of work, and to achieve better performance and efficiency along with higher comfort and safety to the operators, it is necessary to design tools, equipment and workplaces keeping in view of the anthropometric data of the agricultural workers.

One major reason for low agricultural productivity in some agricultural regions is due to prevalence of traditional method of cultivation and lower mechanization level. Machines or tools manufactured without application of human factors or ergonomic principles are low in working efficiency and most times fail to reduce drudgery and increase discomfort of the operators. Ergonomics is the science which considers human characteristics, expectations and behavior in the design of things mainly used in environment (Sanders and McCormic , 1992). The ergonomic principles or human factors are considered in machine design to enhance effectiveness, efficiency, safety and comfort of the users/operators of the equipment. In most cases, constraints are been experienced in adoption of improved machineries being utilized in other parts of the country; the adopted equipment at times need to be modified before being introduced into other countries or regions to suit agricultural workers of the region for which body dimensions limits of local populations was required. To design any product for human use, engineers have to rely on anthropometric data, otherwise the resulting product may turn out to be ergonomically incompatible (Lewis, 1993; Hastegrave, 1986).

According to Mebarki and Davis (1990), anthropometric dimensions are one of the essential factors in designing machines and device. Gite and Yadav (1989), noted that the design and dimensions of agricultural tools and implements have great bearing on the body dimensions and physical built of the users, requiring compatibility essentially between machine devices and worker body dimensions. Dewangan et al., (2005) suggested that the only way to fulfill this objective is to create database of anthropometric dimensions of the user population. 
Gupta et al (1983) observed that most of the anthropometric data in India is limited to male agricultural workers; while it was discovered by Reddy et al., (1994) that about $88 \%$ rural women working population is engaged in agricultural sector and stipulated that the value is nearly $50.2 \%$ of the total agricultural labour force in India. Dixit et al., (2014) added that due to paucity of female anthropometric data, the anthropometric data of male workers are extrapolated to define women at work whenever necessary. Cox et al., (1984) opposed this assumption and said that such an approach is likely to be inaccurate due to obvious anthropometric, physiological and biological differences between male and female subjects. As earlier noted in this review, the body dimensions vary with age, sex, ethnic groups (Sanders and McCormick, 1992). According to Dixit and Namigial (2012), there is considerable difference between the anthropometric data of India and Western population emphasizing the need for generating anthropometric database for agricultural workers as it is not feasible practically to design equipment for an individual sex (male and female).

Based on the foregoing, this study was conducted to generate and analytically compare the anthropometric data of the male and female agricultural workers in the rural areas of south-eastern region of Nigeria. The data so generated will be compared with those of other regions of the western countries for the consideration of ergonomic design of agricultural equipment and machines which will suit the male and female agricultural workers in the study area to enhance effectiveness, efficiency of production, safety and comfort of the users/ operators of the machines.

The placement of different controls in a tractor is a complex task for the designer and requires the anthropometric characteristics of the target population (Yadav et al., 2000). The efficiency and comfort of the operator can be improved with properly designed tractor workplace. The dimensions of the seat, location of controls and access/exit provisions are the parameters where anthropometric data can provide help in matching the workplace according to the user's capabilities and to the physiological reach of the operator.

For design purpose, Yadav et al., (2000) stipulated that either one of the boundary value $\left(5^{\text {th }}\right.$ or $95^{\text {th }}$ percentile) or the mean values is used depending upon the dimensional element. Anthropometrically, the authors noted that seat height from foot rest to suit female Indian $5^{\text {th }}$ and $95^{\text {th }}$ percentile population would be within the range of 37.0 to $40.0 \mathrm{~cm}$. While in the case of male Indians would be within the range of 41.6 to $47.1 \mathrm{~cm}$. If the equipment is to be operated by women, the anthropometric data of the female must be considered in the design along with men anthropometric data. Anonymous (1996) revealed that most Indian tractors are manufactured to suit the anthropometric measurements applicable to the countries where the tractors are designed.

The objective of this research work is to develop an anthropometric database for agricultural field machinery operators in Abia state and any other region with similar anthropometric dimensions for a better design of farm machinery to suit them for safety, comfort and efficient operation in sitting positions. 


\section{MATERIALS AND METHODS}

\section{Samples for the Study}

The samples for the study consist of 400 tractor operators (200 each of male and female) within the age limit of 18-50 years selected randomly from different areas of Abia states.

\section{Apparatus Used}

The following anthropometric equipment was used for the study:

1. An anthropometer was used in measuring various body dimensions at sitting postures.

2. Weighing balance of $1 \mathrm{~kg}$ sensitivity and $150 \mathrm{~kg}$ capacity was used for measuring the body weight of the subjects.

3. Measuring tape was used for measuring lengths and widths of some body parts.

4. Vernier caliper was used for measuring the internal and external grip diameters.

5. Grip strength dynamometer was used for measuring grip strength.

\section{Anthropometric Measurement Procedure/Data Collection}

Thirteen (13) anthropometric body dimensions considered useful for design of agricultural equipment/machines operated in sitting position were measured. The standard anthropometric definitions of measurements and techniques used by Pheasant (1986) as applied by Onuoha et al., (2012) were adopted in the study. Prior to the collection of the data, some persons (male and female) were trained on how to take measurements of body dimensions (Oduma, 2017). The process for data collection was properly explained to the trained personnel so as to maintain accuracy in their measurements and to seek full cooperation from the subjects (Agrawal et al., 2010 and Dixit et al., 2014). Measurements were taking in sitting postures. In process the subjects were asked to sit with their body vertically erect, while their shoulders and head touch the vertical plane and their feet completely touch the base platform. In all the measurements with anthropometer, the subjects were bare footed. The measuring tape was used to measure waist breadth, waist circumference, foot length, and hand breadth across thump, hand height at metacarpal etc. For every subject, measurements of a given body dimension was replicated for five times and average value of the dimension was taken as the real dimension; this is to avoid error in the measurements.

\section{Data Analysis}

The data collected from the measurement was analyzed using range, mean, standard deviation, percentile values $\left(5^{\text {th }}, 50^{\text {th }}\right.$ and $95^{\text {th }}$ percentile) and percentages. The percentile was used to adjudge the proportion of a group of individuals who exceed or fall below some possible design limit. 
Apart from the mean; the $5^{\text {th }}$ and $95^{\text {th }}$ percentile values of body dimensions were calculated to decide various possible sitting design limits of farm machinery and work place layout to be operated by tractor operators (Agrawal 2010).The percentage was used to determine the percentage difference or variation in the set of data obtained for male and female operators (Oduma, 2017).

The percentile was calculated from the formula suggested by Kothari (2013) as used by Oduma (2017).

$$
\mathrm{X}=\mu+\mathrm{ZQ}
$$

Where is:

$$
\begin{aligned}
& X=\text { Percentile } \\
& \mu=\text { mean values } \\
& Q=\text { standard deviation } \\
& Z=\text { constant }=-1.645 \text { for } 5^{\text {th }} \text { percentile; } 0 \text { for } 50^{\text {th }} \text { and } 1.645 \text { for } 95^{\text {th }}
\end{aligned}
$$

percentile

The standard deviation was computed using the expression:

$$
\mathrm{S}=\sqrt{\frac{\Sigma f(Y-\bar{Y})^{2}}{N}}
$$

Where $\quad \mathrm{S}=$ standard deviation

$\Sigma=$ symbol of summation

$\mathrm{f}=$ frequency

$\mathrm{Y}=$ measures of body dimensions

$\overline{\mathrm{Y}}=$ mean values of body dimension given as

$\frac{\Sigma f Y}{N}$

$\mathrm{N}=$ number of subjects measured 


\section{RESULTS AND DISCUSSION}

Table 1. Anthropometric dimensions of tractor Male operators in Abia state

\begin{tabular}{|c|c|c|c|c|c|c|c|}
\hline \multirow{3}{*}{ Body dimensions } & \multicolumn{7}{|c|}{ Male } \\
\hline & \multicolumn{3}{|c|}{ Range } & & \multicolumn{3}{|c|}{ Percentiles } \\
\hline & Min & $\max$ & Mean & S.D & $5^{T H}$ & $50^{T H}$ & $95 T H$ \\
\hline $\begin{array}{l}\text { Hand } \\
\text { length }\end{array}$ & 15.2 & 23.9 & 19.55 & 3.8 & 13.30 & 19.55 & 25.81 \\
\hline $\begin{array}{l}\text { Elbow } \\
\text { height }\end{array}$ & 90.4 & 118.1 & 104.25 & 4.9 & 96.19 & 105.25 & 12.31 \\
\hline $\begin{array}{l}\text { Elbow } \\
\text { rest height }\end{array}$ & 16.7 & 33.2 & 24.95 & 3.3 & 19.52 & 24.95 & 30.38 \\
\hline Hand circumference & 15.2 & 25.6 & 20.9 & 1.6 & 18.27 & 20.9 & 23.53 \\
\hline forearm grip reach & 59.1 & 91.3 & 75.20 & 0.6 & 74.38 & 75.20 & 76.02 \\
\hline Sitting height & 64.2 & 99.3 & 81.75 & 5.1 & 73.36 & 81.75 & 90.14 \\
\hline Sitting eye height & 56.8 & 80.2 & 68.50 & 0.3 & 68.00 & 68.50 & 68.99 \\
\hline Sitting shoulder height & 44.2 & 63.8 & 54.00 & 5.8 & 44.45 & 54.00 & 63.54 \\
\hline Hip breadth & 28.6 & 37.4 & 33.00 & 0.6 & 36.41 & 33.00 & 33.99 \\
\hline Knee height & 47.2 & 64.4 & 55.80 & 1.6 & 53.17 & 55.8 & 58.43 \\
\hline Buttock knee length & 43.7 & 70.4 & 57.05 & 4.8 & 49.15 & 57.05 & 64.95 \\
\hline Functional leg length & 80.3 & 110.2 & 95.25 & 7.0 & 83.74 & 95.25 & 106.77 \\
\hline Foot length & 20.6 & 44.5 & 32.55 & 0.8 & 31.23 & 32.55 & 33.87 \\
\hline
\end{tabular}


Table 1a: Anthropometric dimensions of tractor Female operators in Abia state

\begin{tabular}{|c|c|c|c|c|c|c|c|}
\hline \multirow{3}{*}{ Body dimensions } & \multicolumn{7}{|c|}{ Female } \\
\hline & \multicolumn{2}{|c|}{ Range } & \multirow[b]{2}{*}{ Mean } & \multirow[b]{2}{*}{$S . D$} & \multicolumn{3}{|c|}{ Percentile } \\
\hline & Min & $\max$ & & & $5 T H$ & $50 T H$ & $95^{T H}$ \\
\hline $\begin{array}{l}\text { Hand } \\
\text { length }\end{array}$ & 14.60 & 21.7 & 18.15 & 3.2 & 12.89 & 18.15 & 23.41 \\
\hline $\begin{array}{l}\text { Elbow } \\
\text { height }\end{array}$ & 88.50 & 112.3 & 100.4 & 3.8 & 94.15 & 100.4 & 106.65 \\
\hline $\begin{array}{l}\text { Elbow } \\
\text { rest height }\end{array}$ & 14.20 & 30.1 & 22.25 & 3.1 & 17.51 & 22.25 & 27.00 \\
\hline Hand circumference & 14.8 & 23.9 & 19.35 & 1.4 & 17.05 & 19.35 & 21.65 \\
\hline forearm grip reach & 55.2 & 89.1 & 75.15 & 1.2 & 73.18 & 75.15 & 77.12 \\
\hline Sitting height & 52.4 & 95.1 & 73.75 & 4.9 & 65.59 & 73.75 & 81.81 \\
\hline Sitting eye height & 52.2 & 78.6 & 65.4 & 0.2 & 65.07 & 65.4 & 65.73 \\
\hline Sitting shoulder height & 40.5 & 59.7 & 50.1 & 5.3 & 41.38 & 50.1 & 58.82 \\
\hline Hip breadth & 25.2 & 34.4 & 29.8 & 0.4 & 29.14 & 29.8 & 30.46 \\
\hline Knee height & 43.4 & 60.8 & 52.1 & 1.8 & 49.14 & 52.1 & 55.06 \\
\hline Buttock knee length & 39.8 & 68.1 & 53.95 & 3.7 & 47.86 & 53.95 & 60.04 \\
\hline Functional leg length & 78.1 & 105.3 & 91.7 & 6.8 & 80.51 & 91.7 & 102.89 \\
\hline Foot length & 18.7 & 40.3 & 29.5 & 1.2 & 27.53 & 29.5 & 31.47 \\
\hline
\end{tabular}


Table 2: Effect of gender on the anthropometric dimension of tractor operators in Abia state

\begin{tabular}{lllllc}
\hline Sources of variation & DF & Sum of squares & Mean squares & F. cal & $\begin{array}{c}\text { F. tab } \\
5 \%\end{array}$ \\
\hline Gender & & & & & 4.21 \\
Body dimensions & 13 & -70945.01 & -70945.01 & $0.08^{N S}$ & 2.03 \\
Error & 13 & 12051818.57 & 39010.56 & $0.04^{N S}$ & \\
Total & 27 & 12488010.82 & & & \\
\hline
\end{tabular}

NS = Not significant

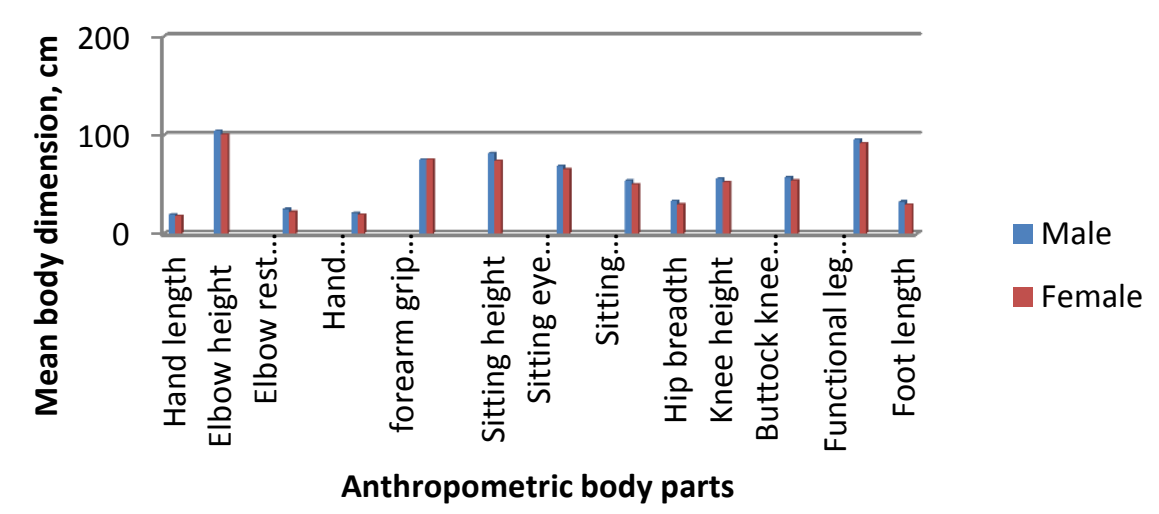

Figure 1: Mean Anthropometric body dimensions of Abia state male and female tractor operators

\section{DISCUSSION}

Table 1., and Table 1a., showed the body dimensions of Abia state male and female agricultural workers in sitting positions. Result revealed that the male agricultural workers have average hand length, elbow height, elbow rest height, hand circumference, and forearm grip reach of male tractor operators are $49.1 \mathrm{~cm}, 38.25 \mathrm{~cm}, 19.55 \mathrm{~cm}, 8.65 \mathrm{~cm}$, and $104.25 \mathrm{~cm}$, respectively while in that same order the female agricultural workers recorded $38.9 \mathrm{~cm}, 36.45 \mathrm{~cm}, 18.15 \mathrm{~cm}, 7.2 \mathrm{~cm}$, and $100.4 \mathrm{~cm}$, respectively. Also result showed that the sitting height, sitting eye height, sitting shoulder height, hip breadth, knee height, buttock knee length, functional leg length, foot length of the male tractor operators are $80.75 \mathrm{~cm}, 81.8 \mathrm{~cm}, 68.5 \mathrm{~cm}, 54.0 \mathrm{~cm}, 33.0 \mathrm{~cm}, 55.8 \mathrm{~cm}, 49.7 \mathrm{~cm}$, and $65.0 \mathrm{~cm}$, respectively; and the female in the same arrangement had $85.8 \mathrm{~cm}, 65.59 \mathrm{~cm}, 65.07 \mathrm{~cm}$, $41.38 \mathrm{~cm}, 29.14 \mathrm{~cm}, 49.14 \mathrm{~cm}, 44.97 \mathrm{~cm}$, and $56.06 \mathrm{~cm}$, respectively.

Figure 1., revealed the mean body dimensions of the male and female tractor operators in Abia state in sitting position. The figure showed that the mean body dimensions of the male are slightly higher than the female except in the hand length, hand circumference and forearm grip reach where they maintained a very close values of $19.55 \mathrm{~cm}, 20.9 \mathrm{~cm}$ and $75.2 \mathrm{~cm}$ respectively for males and $18.15 \mathrm{~cm}, 19.35 \mathrm{~cm}$ and $75.15 \mathrm{~cm}$ respectively for female operators. However, the discrepancies in the rest of the dimensions are very infinitesimal and could be ignored in tractor design. 
The ANOVA of the effect of gender on the anthropometric body dimensions of Abia state male and female tractor operators (Table 2) revealed that there is no significant difference among the body dimensions of male and female tractor operators, hence $\mathrm{P}<0.05$. Thus, the body dimensions of the male and female in Abia state do not differ much, therefore, tools and equipment designed based on data collected can effectively be utilized by both male and female agricultural workers within the region, which is in agreement with the study of Agrawal (2010) and also observed by Oduma and Oluka (2017).

\section{CONCLUSION}

From the findings made, the following conclusions can be drawn about the study: The mean body dimensions of the male are slightly higher than the female except in the hand length, hand circumference and forearm grip reach where they maintained a very close values of $19.55 \mathrm{~cm}, 20.9 \mathrm{~cm}$ and $75.2 \mathrm{~cm}$ respectively for males and $18.15 \mathrm{~cm}$, $19.35 \mathrm{~cm}$ and $75.15 \mathrm{~cm}$ respectively for female operators. However, the discrepancies in the rest of the dimensions are very infinitesimal and could be ignored in tractor design.

The ANOVA of the effect of gender on the anthropometric body dimensions of Abia state male and female tractor operators revealed that there is no significant difference among the body dimensions of male and female tractor operators, hence $\mathrm{P}<$ 0.05 .

Recommendation: Based on the above conclusions, it is therefore recommended that study of anthropometric body dimensions should be extended to different geographical regions of Nigeria to guide the engineers or designers of agricultural equipment in designing and manufacturing the equipment to match the users and make them work in good postures and maximize their output.

\section{REFERENCES}

[1] Agrawal, K.N, Singh, K.P, and Satapathy, K. K. (2010). Anthropometric consideration for farm tools/machinery design for tribal workers of North Eastern India.

[2] Anonymous (1996). Basic human body measurements for technological design. Iso 7250, International standard organization Geneva.

[3] Cox, T, Thirlaway, M, and Cox, S. (1984). Occupational well-being, sex difference at work. Ergonomics 27(5):499-510.

[4] Dewangan, K. N.,Prasanma, G.V, Suja, P. L and Choudhury, M. D (2005). Anthropometric dimensions of farm youth of the north eastern region of India. International Journal of Industrial Ergonomics, 35(11): 979-989.

[5] Dixit, J. and Namgial, D. (2012). Anthropometry of farm workers of Kashmir region of India for equipment design. Journal of agricultural engineering 49(2): 8-15.

[6] Dixit, J. and Namgial, D. Sharma, S., Loanan, S.K, Kumar, D.(2014). Anthropometric survey of farm workers of ladakl region of India and its application in equipment design. Agric eng. Int; CIGR Journal. 16(2):80-88

[7] Gite, L. P. and Yadav, B.G. (1989). Anthropometric survey of agricultural machinery design. Applied Ergonomics. 20(3):191-196. 
[8] Gupter, P.K., Sharma, A. P.,Gupter,M.L.(1983). Anthropometric survey of Indian farm workers. Agricultural mechanization in Asia. Africa and Latin America. 16(1):27-30.

[9] Hastegrave, C.M. (1986). Anthropometric profile of British car drivers. Ergonomics, 23(5):437-467.

[10] Kothari C. R. (2013). Research methodology. methods and techniques: second revised edition. New Age International Publishers. New Delhi. Pp185-344.

[11] Lewis, W. G and Narayan, C.N. (1993). Design and sizing of ergonomic handles for hand tools. Applied Ergonomics, 24(5): 351-356.

[12] Marbarki, B. and Davis, B. T (1990). Anthropometry of Algeria women. International Journal of Industrial Ergonomics. 33(12): 15337-1547

[13] Oduma O. and S. I. Oluka (2017). Comparative analysis of anthropometric dimensions of male and female agricultural workers in south-eastern Nigeria. Nigerian Journal of Technology (NIJOTECH) Vol. 36, No. 1, January 2017, pp. 261 - 266

[14] Onuoha, S. N. Idike F. I and Oduma, O. (2012). Anthropometry of South-Eastern Nigeria Agricultural Workers. International Journal of Engineering and Technology. 2(6):962-968.

[15] Pheasant, S. (1986). Body-space: anthropometry, ergonomics and design. Taylor and Francis, London.

[16] Reddy, A. R, Reddy, Y.S. and Reddy, P. M.(1994). Women and rural development. A case study of DWCRA in Cuddapah district. Kurukshetra, 9:19-21.

[17] Sanders, M. S and McCormic, E. J. (1992). Human factors in engineering and design. McGraw-Hill International Edition McGraw-Hill Incorporation, Singerpore.

[18] Yadav, R.L.P, Gite, N. K, and Randhawa, J. (2000). An anthropometric of India female agricultural workers: agricultural mechanization in Asia. Africa and Latin America, 31(3); 56-60.

\section{ANTROPOMETRIJSKA PROCENA SEDIŠTA TRAKTORA ZA MUŠKARCE I ŽENE U DRŽAVI ABIA (NIGERIA)}

\section{Goziechukwu Inekwe ${ }^{1}$, Okechukwu Oduma ${ }^{1 * *}$, Chukwulebile S. Agu ${ }^{2}$, Clifford E. Igboayaka ${ }^{2}$ and Chineze G. Okeke ${ }^{3}$}

${ }^{l}$ Department of Agricultural \& Bioresources Engineering, Michael Okpara University of Agriculture, Umudike

${ }^{2}$ Department of Mechanical Engineering, College of Engineering and Engineering Technology, Michael Okpara University of Agriculture, Umudike, Abia state, Nigeria. ${ }^{3}$ Department of Agricultural and Bioresources Engineering, Enugu state University of Science and Technology, Enugu

Sažetak: Antropometrijske procene dimenzije korisnika karoserije traktora (muškarci i žene) u državi Abia (Nigeria) su proučavane zbog dobijanja baze podataka za dimenzije karoserije kako bi konstruktori traktora i poljoprivredne opreme bolje dizajnirali mesto (sedište i kabinu) gde operateri rade u sedećim položajima.

Dizajneri traktora tako mogu da poboljšaju svoj dizajn i optimiziju njegovu upotrebu i poboljšaju držanje i udobnost korisnika mašine za najveći učinak u radu. 
Rezultat istraživanja je pokazao da poljoprivredni radnici (muški) imaju prosečnu dužinu ruku, širinu ruku, dohvat ruku od zida, visinu lakta, visinu oslonca za laktove, čvrstoću držanja, unutrašnji i spoljni prečnik držanja, obim šake, dužinu podlaktice i opseg dohvata napred, imao je vrednosti $161.05 \mathrm{~cm}, 49.1 \mathrm{~cm}, 143.75 \mathrm{~cm}, 38.25 \mathrm{~cm}$, $19.55 \mathrm{~cm}, 8.65 \mathrm{~cm}, 85.75 \mathrm{~cm}, 104.25 \mathrm{~cm}, 24.9 \mathrm{~cm}, 41.6 \mathrm{~kg}, 4.7 \mathrm{~cm}, 7.35 \mathrm{~cm}, 7.35 \mathrm{~cm}$, $49.9 \mathrm{~cm}$, odnosno $75.2 \mathrm{~cm}$. Istim redosledom parametara, žene poljoprivredne radnice imale su vrednosti: $150,55 \mathrm{~cm}, 38,9 \mathrm{~cm}, 138,6 \mathrm{~cm}, 36,45 \mathrm{~cm}, 18,15 \mathrm{~cm}, 7,2 \mathrm{~cm}, 82,35$ $\mathrm{cm}, 100,4 \mathrm{~cm}, 22,25 \mathrm{~cm}, 40,25 \mathrm{~kg}, 4,0 \mathrm{~cm}, 6,7 \mathrm{~cm}, 19,55 \mathrm{i} 75,15 \mathrm{~cm}$.

Takođe je rezultat ispitivanja pokazao da: visina sedenja, visina preglednosti, visina kukova, visina kolena, dužina kolena, funkcionalna dužina nogu, dužina stopala muških poljoprivrednih radnika iznosi: $80,75 \mathrm{~cm}, 81,8 \mathrm{~cm}, 68,5 \mathrm{~cm}, 54,0 \mathrm{~cm}, 33.0 \mathrm{~cm}, 55.8 \mathrm{~cm}$, $49.7 \mathrm{~cm}, 65.0 \mathrm{~cm}, 57.05 \mathrm{~cm}, 48.65 \mathrm{~cm}, 95.25 \mathrm{~cm}, 32.55 \mathrm{~cm}, 14.35 \mathrm{~cm}$, i $66.05 \mathrm{~cm}$, respektivno. Kod žena, isti raspored parametara ima vrednosti: $85,8 \mathrm{~cm}, 65,59 \mathrm{~cm}$, $65,07 \mathrm{~cm}, 41,38 \mathrm{~cm}, 29,14 \mathrm{~cm}, 49,14 \mathrm{~cm}, 44,97 \mathrm{~cm}, 56,06 \mathrm{~cm}, 47,86 \mathrm{~cm}, 36,58 \mathrm{~cm}$, $80,51 \mathrm{~cm}, 27,53 \mathrm{~cm}, 3,55 \mathrm{~cm}$, odnosno $79,19 \mathrm{~cm}$, respektivno .

Ključne reči: antropometrija, dimenzije, operatori, tractori, sedeće pozicije.

Prijavljen:

Submitted:

Ispravljen:

Revised:

Prihvaćen:

Accepted:
20.09.2019.

10.10.2019.

30.10.2019. 